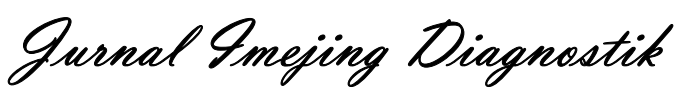

e-ISSN 2621-7457, p-ISSN 2356-301X

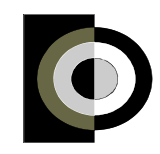

http://ejournal.poltekkes$\underline{\text { smg.ac.id/ojs/index.php/jimed/index }}$

\title{
Verifikasi Neometri Kanker Nasofaring Dengan Epid Pada Pesawat Linac Di Unit Radioterapi Instalasi Radiologi RSUP DR. Kariadi Semarang
}

\author{
Ardi Soesilo Wibowo ${ }^{1}$, Wiratno Wiratno ${ }^{2}$, Bagus Abimanyu ${ }^{3}$, Panji Wibowo Nurcahyo ${ }^{4}$ \\ 1, 3, ${ }^{4}$ Poltekkes Kemenkes Semarang, Indonesia \\ ${ }^{2}$ RS Paru Dr. Ario Wirawan Salatiga, Indonesia \\ Corresponding author: Ardi Soesilo Wibowo \\ e-mail : ardiswjtrr@poltekkes-smg.ac.id
}

Received: January $4^{\text {th }}, 2021$; Revised: January $31^{\text {st }}, 2021$; Accepted: February $1^{\text {st }}, 2021$

\begin{abstract}
Background: In Indonesia, nasopharyngeal cancer ranks 4th most in malignancies. As a method of treatment, the development of radiotherapy has made it possible to give high doses to tumors with little risk of healthy tissue, but still maintain accuracy by performing geometry verification procedures. The purpose of this study was to determine the geometry verification procedure of nasopharyngeal cancer with EPID on the Linac plane in RSUP Dr. Kariadi Semarang; the average geometric shift that occurs and why is only done before fractions 1 and 4 only.

Methods: This type of research is qualitative with a case study approach. The data is taken from February 2019 to June 2019 by the method of observation, documentation and interviews. The data obtained were analyzed by interactive models, making transcripts of interviews then reduced and processed in the form of open coding, presented in the form of quotations and concluded.

Results: The results showed that the geometry verification procedure was started by making a calendar treatment, adjusting the patient's setup at the origin point, switching to the iso center point. Take the image portal with EPID AP and Lateral projections. Match image portals with DRR images. Then the geometric shift data were obtained with a mean shift from the iso center in 5 patient samples: vertical axis $0.15 \mathrm{~cm}$ to superior; longitudinal $-0.01 \mathrm{~cm}$ anteriorly and laterally $0.04 \mathrm{~cm}$ to the right. Tolerance limit of $0.3 \mathrm{~cm}$. This verification is only done before fractions 1 and 4 because of the high service load.

Conclusion: The geometry verification procedure has been going well with the results of the shift is still below the tolerance limit. Verification information before the 1st and 4th fractions was not enough to assess the accuracy of the irradiation carried out properly maintained.
\end{abstract}

Keyword : radiotherapy; geometry verification; nasopharyngeal cancer.

\section{Pendahuluan}

Kanker nasofaring merupakan karsinoma yang muncul pada daerah nasofaring (area di atas tenggorok dan di belakang hidung), yang menunjukkan bukti adanya diferensiasi skuamosa mikroskopik ringan atau ultrastruktur.Di Indonesia,kanker nasofaring merupakan keganasan terbanyak ke-4 setelah kanker payudara, kanker leher rahim, dan kanker paru. Angka kejadian tertinggi di dunia terdapat di propinsi Cina Tenggara yakni sebesar 40 - 50 kasus kanker nasofaring di antara 100.000 penduduk (Kemenkes, 2017).

Terapi dalam pengobatan kanker nasofaring dapat mencakup : radiasi, kemoterapi, kombinasi keduanya dan didukung dengan terapi simptomatik sesuai dengan gejala. Untuk terapi dengan radiasi, daerah nasofaring dibedakan menjadi daerah tumor yang menjadi target radiasi dan organ kritis (Organ At Risk) yang merupakan jaringan sehat di sekitar tumor yang beresiko mendapatkan penyinaran berlebih. Pada kanker nasofaring banyak dijumpai organ kritis yang dapat membatasi pemberian dosis maksimal tumor. Organ kritis daerah nasofaring antara lain : batang otak, medula spinalis, chiasma optikum, mata, lensa mata, nervus optikus, dan kelenjar parotis.

Perkembangan teknologi dalam pengobatan kanker nasofaring telah memungkinkan diberikannya dosis radiasi yang tepat ke tumor ganas atau area spesifik di dalam tumor. Pemberian radioterapi dalam bentuk IMRT (Intensity Modulated Radiotherapy) lebih dipilih untuk kasus kanker nasofaring (Kemenkes, 2017). Dengan menggunakan teknik seperti IMRT, ahli onkologi radiasi dapat memaksimalkan kemampuan 
menghancurkan kanker dan meminimalkan dampak pada jaringan dan organ sehat serta efek samping yang menyertainya (Chao KSC, 2008)

Disamping itu, teknologi pengobatan dengan radiasi juga mendukung prosedur verifikasi geometri dengan lebih baik. Karena ketidakpastian geometri akan selalu ditemukan dalam suatu proses radioterapi eksternal, maka berbagai perangkat diciptakan untuk memudahkan melakukan konfirmasi penyinaran bahwa lokasi atau target radiasi sudah sesuai dengan yang direncanakan, sehingga dapat menjamin bahwa penyinaran yang sedang dilakukan akurat. Sumber dari ketidakpastian ini dapat berasal dari pasien maupun teknik, baik dalam perencanaan maupun pelaksanaan radiasi (Adam cit.Van Herk, 2004). Kesalahan yang terkait dengan pasien antara lain : ketidak-tepatan delineasi tumor atau GTV, ketidaktahuan ekstensi mikroskopis tumor atau CTV, variasi posisi organ-organ tubuh dan pergerakan yang terjadi saat dilakukan radioterapi. Sedangkan kesalahan teknik berupa variasi dalam set up, seperti : kedudukan laser, meja pasien, pencitraan yang dilakukan, serta alat imobilisasi yang digunakan (Adam cit. Stroom J, 2000)

Menurut Kemenkes (2017) penyinaran pada kanker nasofaring dengan teknik IMRT, verifikasi set up dengan EPID wajib dilakukan setiap fraksi pada 5 fraksi pertama, diikuti dengan setiap 5 fraksi. Untuk teknik 3D-CRT (3 Dimention-Conformal Radiotherapy), verifikasi set up dengan EPID wajib dilakukan setiap fraksi pada 3 fraksi pertama, diikuti dengan setiap 5 fraksi. Demikian juga menurut Hoskin (2007), verifikasi dilakukan sebelum 3 fraksi pertama, pada fraksi 4 dan 5 didasarkan pada rerata nilai pergeseran verifikasi sebelumnya dan verifikasi selanjutnya setiap 5 fraksi. Adapun di Unit Radioterapi Instalasi Radiologi RSUP Dr. Kariadi, kegiatan verifikasi set up pada kanker nasofaring dilakukan sebelum fraksi 1 dan 4 . Oleh karena itu peneliti tertarik dan mengangkatnya dalam tugas akhir dengan judul "Verifikasi Geometri Kanker Nasofaring dengan EPID pada Pesawat Linac di Unit Radioterapi Instalasi Radiologi RSUP Dr. Kariadi Semarang."

Tujuan penelitian ini adalah untuk mengetahui prosedur verifikasi geometri kanker nasofaring dengan EPID pada pesawat Linac di RSUP Dr. Kariadi Semarang, seberapa banyak pergeserannya dan mengapa hanya dilakukan sebelum fraksi ke 1 dan 4 saja.

\section{Metode}

Jenis penelitian ini adalah penelitian kualitatif dengan pendekatan studi kasus. Subyek penelitian terdiri atas : 1 orang dokter spesialis onkologi radiasi dengan kriteria terlibat langsung dalam melakukan terapi radiasi pada pemeriksaan kanker nasofaring; 1 orang fisika medis dengan kriteria mendesain arah berkas sinar; 2 orang radiografer radioterapis, dengan kriteria terlibat langsung dalam melakukan verifikasi geometri kanker nasofaring dengan EPID pada pesawat Linac; 5 orang pasien, di mana 1 sampel mewakili paparan kasus dan prosedur verifikasi geometri, sedangkan 4 sampel hanya diambil hasil pergeseran pada bidang orthogonal, kemudian hasil pergeseran 5 sampel pada setiap bidang orthogonal tersebut dianalisa dan didapatkan hasil rerata pergeseran.

Pengambilan data dilakukan pada bulan Pebruari 2019 sampai dengan bulan Juni 2019 dengan metode observasi, dokumentasi dan wawancara. Data yang diperolah dianalisa dengan model interaktif, membuat transkip wawancara kemudian direduksi dan diolah dalam bentuk koding terbuka, disajikan dalam bentuk kuotasi dan diambil kesimpulan.

\section{Hasil Dan Pembahasan}

\section{Paparan Kasus}

Dari hasil anamnesa awal dokter pengirim pada pasien didapatkan informasi : telinga kiri terasa berbunyi dan berdenyut sejak 4 bulan yang lalu, nyeri kepala dan pandangan double. Ada benjolan leher di sisi kiri sejak 1 bulan yang lalu dan mulai susah menelan. Pasien dirujuk untuk dilakukan pemeriksaan penunjang berupa : Patologi Anatomi, USG Abdomen dan MSCT Nasofaring dengan Kontras. Hasil pemeriksaan penunjang tersebut pasien didiagnosa menderita $\mathrm{Ca}$ Nasofaring Stadium $\mathrm{T}_{4} \mathrm{~N}_{2} \mathrm{M}_{0}$. Selanjutnya pasien dirujuk ke unit radioterapi untuk dilakukan pengobatan. Dokter spesialis onkologi radiasi menentukan pengobatan radioterapi definitif dengan teknik radiasi eksterna. Total dosis yang akan diterima sebesar 70 Gray dengan pemberian dosis 2 Gray selama 35 Fraksi.

Prosedur verifikasi geometri kanker nasofaring dengan EPID pada pesawat Linac di RSUP Dr. Kariadi Semarang

\section{siapan Alat dan Bahan}

Persiapan alat dan bahan pada prosedur verifikasi geometri kanker nasofaring dengan EPID pada pesawat Linac di Unit Radioterapi Instalasi Radiologi RSUP Dr.Kariadi Semarang terdiri dari : pesawat radioterapi yang dilengkapi dengan EPID, komputer Aria, data penyinaran, treatment calender, masker thermoplastic 4 point, selimut, 
sabuk pengaman, plester, spidol 2 warna, bantal no.4, wedge no. 9 dan plate.

Menurut Hoskin (2007), kegiatan verifikasi perlu mempertimbangkan infrastruktur teknis dan peralatan, pengukuran variasi set up error, protokol pencitraan verifikasi, toleransi dan koreksi. Alat fiksasi yang digunakan juga harus mencakup daerah bahu, karena lapangan penyinaran juga mencakup daerah leher bawah dan fossa supra clavikula.

Menurut peneliti, peralatan dan bahan yang digunakan sudah sesuai dengan teori. Hal ini dapat dilihat dengan adanya pesawat Linac yang dilengkapi dengan EPID, data planning penyinaran TPS yang dikirim dan diolah menjadi treatment calender dengan pesawat Aria sebelum ditransfer ke pesawat Linac, juga dilengkapi sofware verifikasi yang dapat dipakai untuk menghitung dan merekam data pergeseran. Spidol 2 warna dan plester sebagai alat penanda titik iso center yang dapat terlihat pada saat radioterapis melakukan set up pasien. Kemudian penggunaan masker thermoplastic 4 point, bantal no.4, wedge no. 9 dan plate, juga memberikan fiksasi dengan sangat baik sehingga meminimalkan pergerakan kepala dan leher pasien. Pada masker thermoplastic tersebut sudah ada penambahan point fiksasi pada setiap bahu, karena set up error paling menonjol adalah daerah bahu dan lapangan sinar juga meliputi daerah leher bagian bawah dan fosa supraklavikula.

Penambahan selimut dan sabuk pengaman memberikan kenyamanan lebih terhadap pasien. Namun penulis belum menemukan adanya pengganjal untuk kedua lutut pasien. Menurut peneliti kedua lutut perlu diganjal karena akan mengurangi curvatura thorakalis pada saat lutut dilipat sehingga permukaan punggung menjadi rata dan rapat di meja pemeriksaan. Hal ini diperlukan untuk meningkatkan kenyamanan pasien, karena pasien dituntut menjaga sikap yang sama dalam waktu yang relatif lama.

Persiapan Pasien

Pasien tidak memerlukan persiapan khusus. Radioterapi hanya meminta mengganti pakaian dengan baju pasien yang telah disediakan. Kemudian memberi edukasi pada pasien sebelum dan sesudah dilakukan verifikasi geometri.

Menurut peneliti, persiapan pasien sebelum dilakukan tindakan verifikasi geometri sudah sangat baik. Pasien diberi edukasi tentang tujuan dan langkah-langkah kegiatannya, diharapkan pasien tidak takut dan bingung sehingga dengan kesadarannya sendiri mau bekerja sama dengan petugas. Edukasi juga diberikan setelah pasien selesai menjalani verifikasi, bahwa ini bukan bagian dari treatment dan agar menjaga daerah yang diterapi tidak terkena air serta meminta pasien datang kembali tepat waktu.

\section{Prosedur Verifikasi Geometri}

Prosedur verifikasi geometri dimulai dengan membuat treatment calender, mengatur set up pasien pada titik origin dan melakukan pergeseran ke titik iso center sesuai dengan perintah pergeseran dari TPS. Kemudian mengambil portal image dan mencocokkannya dengan citra DRR, sehingga didapatkan data pergeseran dari titik iso center. Pengambilan kembali gambar dilakukan bila besar pergeseran melebihi batas toleransi dan pasien telah diposisikan kembali sesuai dengan pergeserannya. Terakhir dilakukan couch copy dan penandaan titik iso center.

Verifikasi geometri tersebut tidak dilakukan dengan pendampingan oleh dokter, kecuali karena kondisi yang mewajibkan adanya pendampingan dokter. Oleh karena itu tidak dilanjutkan dengan proses penyinaran karena hasil verifikasi belum divalidasi oleh dokter spesialis onkologi radiasi.

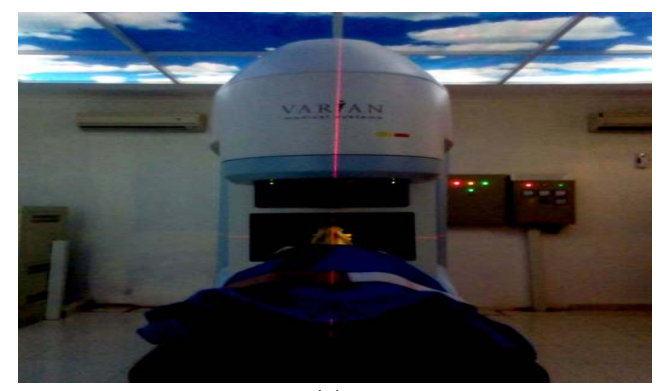

(a)

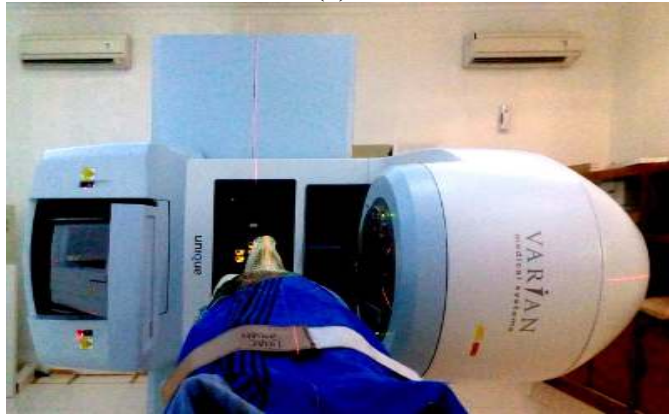

(b)

Gambar 1

Pengambilan portal image

(a) proyeksi AP (b) proyeksiLateral 


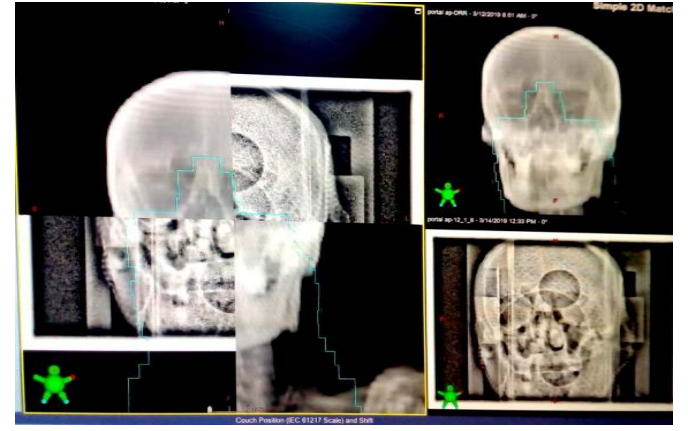

(a)

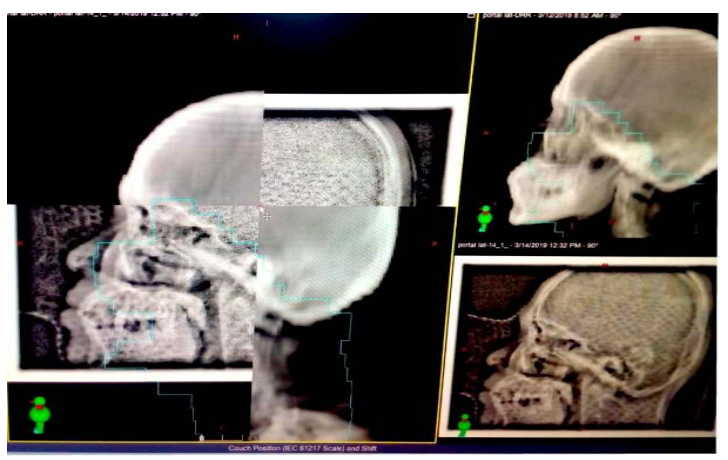

(b)

Gambar 2

Proses pencocokan portal image dengan citra DRR pada verifikasi ke 1

(a) Proyeksi AP (sumbu lateral dan sumbu longitudinal)

(b) Proyeksi Lateral (sumbu vertikal).

Tabel 1 Hasil verifikasi geometri Tn. $\mathrm{H}$ sebelum fraksi ke 1

\begin{tabular}{cccc}
\multicolumn{3}{c}{ Posisi meja (cm) } & \\
\cline { 1 - 3 } Lertikal & Longitudinal & Lateral & \\
$-15,6$ & 92,6 & $-15,6$ & Target \\
$-15,6$ & 92,6 & $-15,6$ & Aktual \\
0 & 0 & 0 & Selisih \\
\hline
\end{tabular}

Berdasarkan tabel 1 di atas hasil pergeseran verifikasi geometri ke 1 pada semua bidang orthogonal tidak menunjukkan nilai yang melebihi batas toleransi, maka tidak dilakukan pergeseran titik iso center.

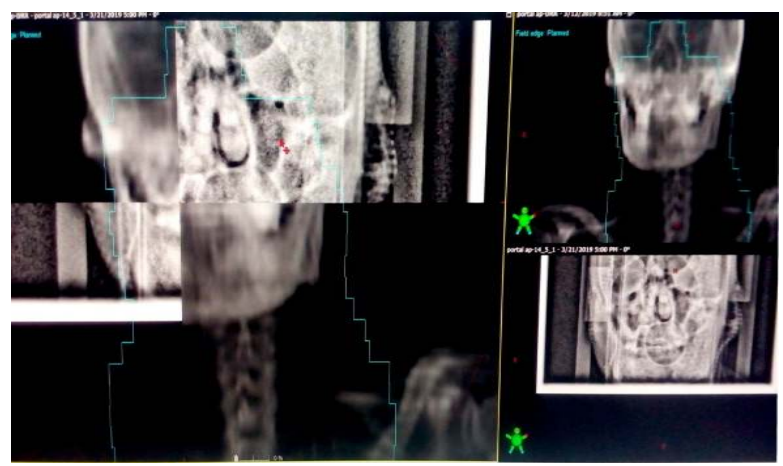

(a)

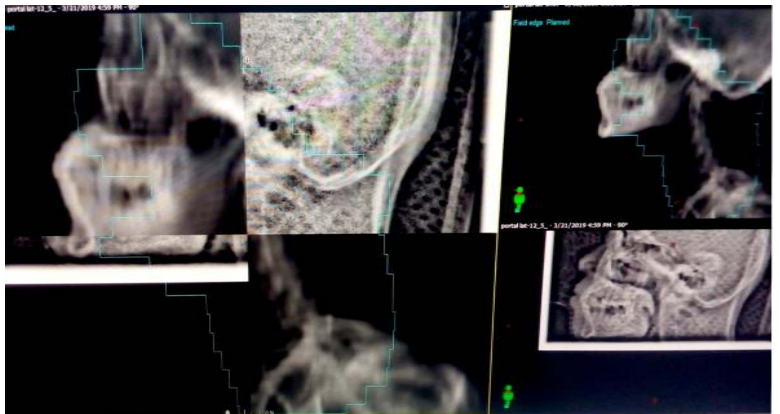

(b)

Gambar 3

Proses pencocokan portal image dengan citra DRR pada verifikasi ke 2

(a)Proyeksi AP (sumbu lateral dan sumbu longitudinal)

(b) Proyeksi Lateral (sumbu vertikal)

Tabel 2 Hasil verifikasi geometri Tn. H sebelum fraksi ke 4

\begin{tabular}{cccc}
\cline { 1 - 2 } Posisi meja (cm) & & \\
\cline { 1 - 3 } Vertikal & Longitudinal & lateral & \\
-15.6 & 92.6 & +0.7 & Target \\
-15.5 & 92.9 & +0.7 & Aktual \\
0.1 & 0.3 & 0 & Selisih \\
\hline
\end{tabular}

Berdasarkan tabel 2 di atas selisih pergeseran terhadap titik iso center pada sumbu vertikal $0,1 \mathrm{~cm}$, menunjukkan adanya pergeseran sebesar $0,1 \mathrm{~cm}$ ke arah superior; pada sumbu longitudinal $0,3 \mathrm{~cm}$, menunjukkan adanya pergeseran sebesar $0,3 \mathrm{~cm}$ ke arah posterior dan pada sumbu lateral $0 \mathrm{~cm}$. Hasil pergeseran verifikasi geometri ke 2 pada semua bidang orthogonal masih menunjukkan nilai ambang batas toleransi maka tidak dilakukan pergeseran titik iso center.

Menurut Hoskin (2007), peran verifikasi terutama untuk mendeteksi kesalahan dalam pemberian terapi dan menilai kesesuaian margin yang direncanakan di sekitar volume target klinis, yang memungkinkan adanya ketidakpastian dalam proses radioterapi. Oleh karena itu proses verifikasi harus dilakukan dalam struktur yang jelas dengan menentukan protokol verifikasi yang sesuai dengan departemennya. Untuk langkah awal perlunya mengidentifikasi ruang lingkup dalam praktek verifikasi, dimana peralatan, manajemen dan protokol yang dipilih bisa menyesuaikan dengan sistem verifikasi yang tersedia di departemen. Selain itu dengan proses verifikasi, tentu beban kerja klinis untuk departemen dapat meningkatkan, dan itu berimbas pada kebutuhan sumber daya pelayanan. Sehingga perlu ada pelayanan yang terencana sejak awal, agar dapat mengoptimalkan keseimbangan antara praktek verifikasi terbaik dan beban kerja pelayanan.

Menurut peneliti, kegiatan verifikasi geometri kanker nasofaring dengan EPID pada pesawat Linac di Unit Radioterapi Instalasi 
Radiologi RSUP Dr. Kariadi Semarang sudah didukung oleh peralatan, manajemen dan protokol yang baik. Hal ini dapat dilihat dengan adanya peralatan : pesawat Linac yang dilengkapi dengan EPID, masker thermoplastic 4 point, bantal, wedge, plate, sabuk pengaman dan selimut. Sedangkan protokol verifikasi dituangkan dalam instruksi kerja yang jelas dan terpantau dengan baik. Kebijakan manajemen juga memastikan bahwa ketepatan jadwal verifikasi menjadi kontrol mutu dalam pelayanan radioterapi.

Oleh karena verifikasi geometri yang dilakukan offline, maka pasien akan mendapatkan penyinaran pertama pada hari berikutnya. Hal ini akan membebani pasien dari segi waktu, biaya dan tenaga. Di samping itu pada pergeseran yang melebihi batas toleransi menurut radiografer radioterapis, namun masih dapat ditoleransi oleh dokter spesialis onkologi radiasi, oleh karena offline maka akan menambah unnecessary atau unintended exposure.

Pergeseran pada Verifikasi Geometri Kanker Nasofaring dengan EPID pada Pesawat Linac di Unit Radioterapi Instalasi Radiologi RSUP Dr. Kariadi Semarang.

Berdasarkan studi dokumentasi yang peneliti lakukan terhadap 5 sampel pasien hasil verifikasi geometri kanker nasofaring sebelum fraksi ke 1 dan ke 4 didapatkan rata - rata pergeseran pada sumbu vertikal sebesar $0,15 \mathrm{~cm}$ ke arah superior, sumbu longitudinal sebesar $-0,01 \mathrm{~cm}$ ke arah anterior, dan sumbu lateral sebesar $0,04 \mathrm{~cm}$ ke arah kanan dari iso center.

Tabel 3 Hasil pergeseran pada sumbu vertikal

\begin{tabular}{cccc}
\hline \multirow{2}{*}{$\begin{array}{c}\text { Nomor } \\
\text { Sampel }\end{array}$} & \multicolumn{2}{c}{$\begin{array}{c}\text { Pergeseran posisi (cm) } \\
\text { pada sumbu vertikal }\end{array}$} & Rerata \\
\cline { 2 - 3 } & \multicolumn{2}{c}{ Fraksi ke } & \\
$\mathbf{1}$ & $+\mathbf{1}$ & $\mathbf{4}$ & \\
$\mathbf{2}$ & $+0,3$ & $+0,3$ & $+0,3$ \\
$\mathbf{3}$ & $+0,1$ & $-0,1$ & 0 \\
$\mathbf{4}$ & $-0,2$ & $-0,2$ & 0,2 \\
$\mathbf{5}$ & $-0,2$ & $-0,2$ & 0,2 \\
& $+0,1$ & 0,0 & 0,05 \\
& & & \\
& & Rata-rata & 0,15 \\
\hline
\end{tabular}

Tabel 3 menunjukkan hasil pengukuran pergeseran pada sumbu vertikal dari 5 sampel pasien pada verifikasi sebelum fraksi ke 1 dan ke 4, didapatkan hasil pergeseran tertinggi pada pasien dengan nomor sampel 1 senilai $0,3 \mathrm{~cm}$ ke arah superior pada verifikasi sebelum fraksi ke 1 dan ke 4, dan pergeseran terendah pada pasien dengan nomor sampel 2 senilai $0 \mathrm{~cm}$ pada verifikasi sebelum fraksi ke 4 .
Tabel 4 Hasil pergeseran pada sumbu longitudinal

\begin{tabular}{|c|c|c|c|}
\hline \multirow{3}{*}{$\begin{array}{l}\text { Nomor } \\
\text { Sampel }\end{array}$} & $\begin{array}{r}\text { Pergese } \\
\text { sum }\end{array}$ & $\begin{array}{l}\text { m) pada } \\
\text { dinal }\end{array}$ & \multirow{3}{*}{ Rerata } \\
\hline & \multicolumn{2}{|c|}{ Fraksi ke } & \\
\hline & 1 & 4 & \\
\hline 1 & $-0,1$ & $-0,1$ & $-0,1$ \\
\hline 2 & 0.1 & 0,1 & 0,1 \\
\hline 3 & $-0,3$ & $-0,2$ & $-0,25$ \\
\hline 4 & 0,2 & 0,2 & 0,2 \\
\hline \multirow[t]{2}{*}{5} & 0,0 & 0,0 & 0,0 \\
\hline & & Rata-rat & $-0,01$ \\
\hline
\end{tabular}

Tabel 4 menunjukkan hasil pengukuran pergeseran pada sumbu longitudinal dari 5 sampel pasien pada verifikasi sebelum fraksi ke 1 dan 4, didapatkan hasil pergeseran tertinggi pada pasien dengan nomor sampel 3 senilai $-0,3 \mathrm{~cm}$ ke arah superior pada verifikasi sebelum fraksi ke 1, dan pergeseran terendah pada pasien dengan nomor sampel 5 senilai $0 \mathrm{~cm}$ pada verifikasi sebelum fraksi ke 1 dan ke 4.

Tabel 5 Hasil pergeseran pada sumbu lateral

\begin{tabular}{|c|c|c|c|}
\hline \multirow{3}{*}{$\begin{array}{l}\text { Nomor } \\
\text { Sampel }\end{array}$} & \multirow{2}{*}{\multicolumn{2}{|c|}{$\begin{array}{c}\begin{array}{c}\text { Pergeseran posisi }(\mathrm{cm}) \text { pada } \\
\text { sumbu lateral }\end{array} \\
\text { Fraksi ke }\end{array}$}} & \multirow{3}{*}{ Rerate } \\
\hline & & & \\
\hline & 1 & 4 & \\
\hline 1 & 0,0 & 0,0 & 0,0 \\
\hline 2 & 0,0 & 0,2 & 0,1 \\
\hline 3 & 0,0 & $-0,1$ & $-0,05$ \\
\hline 4 & 0,0 & 0,3 & 0,15 \\
\hline \multirow[t]{2}{*}{5} & 0,0 & 0,0 & 0,0 \\
\hline & & Rata-rat & 0,04 \\
\hline
\end{tabular}

Tabel 5 menunjukkan hasil pengukuran pergeseran pada sumbu longitudinal dari 5 sampel pasien pada verifikasi sebelum fraksi ke 1 dan 4 , didapatkan pergeseran tertinggi pada pasien dengan nomor sampel 4 senilai $0,3 \mathrm{~cm}$ ke arah superior pada verifikasi sebelum fraksi ke 4, dan pergeseran terendah pada pasien dengan nomor sampel 2,3,4 senilai $0 \mathrm{~cm}$ hanya pada verifikasi sebelum fraksi ke 1 , sedangkan untuk pasien dengan nomor sampel 1 dan 5 pada verifikasi sebelum fraksi ke 1 dan ke 4 .

Batas toleransi pergeseran geometri yang ditetapkan di RSUP Dr. Kariadi Semarang pada kanker nasofaring dengan pesawat Linac sebesar $0,3-0,5 \mathrm{~cm}$.

Sesuai dengan ICRU, ketidakpastian akibat set-up dan posisi organ harus dikompensasi dalam perencanaan radioterapi dengan memberikan margin di sekeliling CTV yang disebut dengan PTV. ICRU juga merekomendasikan untuk memberikan margin pada organ at risk (OAR) yang disebut dengan planning organ at risk volume (PRV). Pada regio kepala dan leher, berbagai publikasi melaporkan besar margin ini bervariasi antara 3 - $9 \mathrm{~mm}$, namun kebanyakan 
merekomendasikan sebesar $5 \mathrm{~mm}$ dengan penggunaan masker thermoplastic sebagai alat imobilisasi standar. (Adam cit. ICRU 62; Stroom J, 2000)

Toleransi yang digunakan dalam praktek akan memperhitungkan beberapa faktor, antara lain : metode imobilisasi, toleransi dari gerakan peralatan dan set-up, dan gerak organ internal. Beberapa keadaan pasien mungkin memerlukan pertimbangan khusus, misalnya mereka yang menderita, cemas atau obesitas. Sedangkan untuk protokol pencitraan, toleransi tergantung pada: situs anatomi, teknik pengobatan, margin CTV-PTV dan kepatuhan pasien (Hoskin, 2007)

Menurut peneliti, penentuan nilai batas toleransi pergeseran di Unit Radioterapi Instalasi Radiologi RSUP Dr. Kariadi Semarang telah sesuai dengan teori. Penentuan nilai toleransi didasarkan pada pertimbangan pemakaian jenis modalitas pesawat radioterapi, alat imobilisasi yang digunakan, dan kebijakan atau regulasi dari rumah sakit yang didasarkan pada perhitungan set up error harian.

Alasan verifikasi geometri kanker nasofaring dengan EPID pada pesawat Linac di Unit Radioterapi Instalasi Radiologi RSUP Dr. Kariadi Semarang dilakukan hanya pada fraksi ke 1 dan 4 saja.

Verifikasi geometri dilakukan sebelum fraksi ke 1 dan 4, dan tidak dilakukan kembali verifikasi sampai proses penyinaran pasien selesai, kecuali diperlukan. Penentuan set up pasien selanjutnya juga bukan merupakan rerata dari pergeseran hasil verifikasi geometri sebelum fraksi ke 1 dan 4. Ketentuan tersebut merupakan kebijakan pimpinan yang didasarkan pada beban pelayanan yang sangat tinggi. Namun ketentuan tersebut tidak bersifat mutlak, hanya berdasarkan pada kebutuhan saat ini.

Penentuan waktu verifikasi menurut Hoskin (2007) dan Kemenkes (2017) didasarkan pada 5 fraksi awal, selanjutnya setiap 5 fraksi. Perbedaannya pada Hoskin untuk fraksi ke 4 dan 5 merupakan rerata dari hasil verifikasi pada fraksi ke 1, 2 dan 3. Selain itu Hoskin tidak mensyaratkan tekniknya, baik 3DCRT maupun IMRT sama. Sedangkan Kemenkes melakukan penyesuaian terhadap realitas di lapangan.

Berdasarkan data wawancara dengan responden, disampaikan bahwa beban pelayanan di ruang penyinaran untuk satu pesawat perhari sekitar $50-60$ pasien. Bila jam kerja efektif 14 jam (7.30 WIB- 21.30 WIB) maka rata-rata untuk 1 pasien membutuhkan waktu pelayanan sekitar $14-16,8$ menit. Responden juga menyampaikan untuk satu kali kegiatan verifikasi dengan keadaan umum pasien baik, membutuhkan waktu 15 - 20 menit. Beban pelayanan yang tinggi dan tuntutan untuk dapat menjaga alur pelayanan tetap baik, menjadi pertimbangan kebijakan bahwa verifikasi geometri dilakukan sebelum fraksi ke 1 dan 4 saja. Namun, sedikitnya kegiatan verifikasi geometri yang dilakukan dibandingkan dengan yang seharusnya, selain mampu menjaga alur pelayanan tetap baik, juga membawa konsekuensi negatif yaitu minimnya informasi yang didapat tentang data pergeseran set up pasien. Informasi ini penting untuk menilai bahwa akurasi penyinaran yang dilakukan tetap terjaga dengan baik. Maka untuk dapat meningkatkan informasi tentang data pergeseran set up pasien, perlu dilakukan penambahan verifikasi geometri pada setiap 5 fraksi. Hal ini diperkuat oleh data responden yang menyatakan bila kebijakan mengenai verifikasi geometri belum sampai pada batas minimal yang harus dilakukan, yaitu 5 kali penyinaran untuk 1 kali verifikasi.

Menurut Hoskin (2007), pemeriksaan verifikasi geometri dengan menggunakan pesawat CT Simulator bisa dipakai untuk menentukan nilai gross error. Dengan ketentuan citra target masih harus diambil pada fraksi pertama di ruang penyinaran dan ditinjau sebelum fraksi berikutnya. Apabila beban pelayanan di ruang CT Simulator masih terbatas, ketentuan ini bisa menjadi alternatif apabila hendak mengurangi beban pelayanan di ruang penyinaran. Peneliti tidak melakukan pengkajian kondisi dan beban pelayanan di ruang CT Simulator.

\section{Simpulan}

Prosedur verifikasi geometri kanker nasofaring dengan EPID pada pesawat Linac di Unit Radioterapi Instalasi Radiologi RSUP Dr. Kariadi Semarang dimulai dengan membuat treatment calender, menyiapkan alat dan bahan, memanggil dan mengedukasi pasien. Kemudian mengatur set up pasien pada titik origin dan menggeser meja ke titik iso center sesuai dengan perintah pergeseran dari TPS. Dilanjutkan mengambil portal image dengan EPID dan mencocokkan dengan citra DRR dari TPS. Selanjutnya diperoleh data hasil pergeseran dari verifikasi.

Besar rata-rata pergeseran lapangan penyinaran dari 5 sampel pasien hasil verifikasi geometri kanker nasofaring sebelum fraksi ke 1 dan ke 4 didapatkan rata - rata pergeseran pada sumbu vertikal sebesar $0,15 \mathrm{~cm}$ ke arah superior, sumbu longitudinal sebesar $-0,01 \mathrm{~cm}$ ke arah anterior, dan sumbu lateral sebesar $0,04 \mathrm{~cm}$ ke arah kanan dari iso center. 
Verifikasi geometri kanker nasofaring hanya dilakukan sebelum fraksi ke 1 dan ke 4 karena beban pelayanan yang tinggi dan tuntutan untuk dapat menjaga alur pelayanan tetap baik. Dan tidak dilakukan verifikasi kembali sampai proses penyinaran pasien selesai, kecuali diperlukan.

Prosedur verifikasi geometri dengan EPID telah dilakukan dengan baik dengan hasil masih di bawah batas toleransi. Namun informasi verifikasi geometri sebelum fraksi ke 1 dan 4 belum cukup untuk menilai akurasi penyinaran yang dilakukan tetap terjaga dengan baik.

\section{Daftar Pustaka}

Chao KSC, Mohan R, Lee NA, et al. Intensity-modulated radiation treatment techniques and clinical applications. In: Halperin EC, Perez CA, Brady $L W$, eds. Perez and Brady's principles and practice of radiation oncology, 5th ed. New York: Lippincott; 2008

Faisal Adam, 2013. Verifikasi Geometri Radioterapi Teknik 3DCRT/IMRT Pada Kasus Kanker Kepala dan Leher Di Departemen Radioterapi RSCM

Hoskin, The Royal College of Radiologists, Society and College of Radiographers, Institute of Physics and Engineering in Medicine. On target: ensuring geometric accuracy in radiotherapy. London: The Royal College of Radiologists; 2008

Kementerian Kesehatan RI, Pedoman Penatalaksaan Kanker Nasofaring, 2017

Stroom JC, Heijmen BJM., 2002, Geometrical uncertainties, radiotherapy planning margins, and the ICRU-62 report. Radiotherapy Oncol 64: 75-83.

Van Herk M., 2004, Errors and margins in radiotherapy. Semin Radiat Oncol; 14 :

52-64 